\title{
Periaortitis, Coronary Vasculitis and Retro-Orbital Pseudotumor in a Patient with Immunoglobulin G4-Related Sclerosing Vasculitis
}

\author{
İmmunoglobulin G4 İlişkili Sklerozan Vaskülitli Hastada Periaortitis, Koroner Vaskülit ve \\ Retro-Orbital Pseudotümör Birlikteliği
}

\author{
Burak BİLGIN, Yakup YEŞILLKAYA, Burcu TÜRKER, Özkan VARAN, Öznur AYDIN, Metin IŞIK, Levent KILIÇ, \\ İsmail DOĞAN, Başak BOLAYIR, Sedat KİRAZ, Enver ATALAR, Mustafa CENGİZ \\ Department of Internal Medicine, Medical Faculty of Hacettepe University, Division of Rheumatology, Ankara, Turkey
}

\begin{abstract}
Immunoglobulin G4 (IgG4)-related sclerosing vasculitis is characterized by extensive IgG4-positive plasma cells and T-lymphocyte infiltration of various organs. Serum IgG4 level and immunostaining with anti-IgG4 antibody are useful for the diagnosis. In this article, a 61-year-old male patient who was admitted with the complaints of dyspnea, diffuse edema and chest pain and presented with increased pericardial fluid and serum lgG4 level was reported. Thoracoabdominal computed tomography (CT) scan demonstrated a soft tissue mass starting at arcus aorta and surrounding thoracal and abdominal aorta. After biopsy was obtained, the patient was diagnosed with IgG4-related sclerosing vasculitis.
\end{abstract}

Key words: IgG4-related sclerosing vasculitis; inflammatory pseudotumor.

After autoimmune pancreatitis (AIP) was described by Yoshida et al., ${ }^{[1]}$ in 1995, many other cases have been reported in the literature, and AIP has become a distinct entity recognized throughout the world. Later Hamano et al., ${ }^{[2]}$ reported that immunoglobulin G4 (IgG-4) levels increase in AIP. On the other hand, the exact pathogenesis and pathophysiology of AIP still remains unclear, and the clinical, radiological, serological, and histopathological characteristics are not well described. However, what we have learned up to now is that in patients with AIP, the serum IgG4 levels are frequently and significantly elevated, and
İmmunoglobulin G4 (IgG4) ilişkili sklerozan vaskülit, çeşitli organlarda yaygın IgG4-pozitif plazma hücreleri ve T-lenfosit infiltrasyonu ile karakterize bir hastalıktır. Serum IgG4 düzeyleri ve anti-IgG4 antikor immün boyamaları tanıda kullanışlıdır. Bu makalede, dispne, yaygın ödem ve göğüs ağrısı yakınmasıyla başvuran ve perikardiyal sıvı ve serum IgG4 düzeyinde artış görülen 61 yaşında bir erkek hasta sunuldu. Torakoabdominal bilgisayarlı tomografi (BT) taramasında aort arktan başlayan ve torakal ve abdominal aortu saran bir yumuşak doku kitlesi saptandı. Biyopsi yapıldıktan sonra, hastaya lgG4 ilişkili sklerozan vaskülit tanısı kondu.

Anahtar sözcükler: IgG4 ilişkili sklerozan vaskülit; inflamatuvar psödotümör.

some other extra-pancreatic lesions are seen. ${ }^{[2,3]}$ The histological and immunohistochemical evaluation of the organs affected by AIP shows dense infiltration of IgG4-positive plasma cells and CD4- or CD8-positive T lymphocytes along with fibrosis in the peri-pancreatic retroperitoneal tissue, bile duct, gallbladder, periportal area of the liver, salivary glands, and the pancreas which may cause inflammatory pseudotumors and lymphadenopathies. ${ }^{[1-3]}$ The disease occurs predominantly in older men, but both the pancreatic and extra-pancreatic lesions respond well to steroid therapy. ${ }^{[4]}$ Rheumatologists must keep IgG4-related 
systemic disease in mind for the differential diagnosis of Sjogren's syndrome in patients with submandibular IgG4-related sclerosing vasculitis and for patients with a systemic disease that is characterized by extensive infiltration of IgG4-positive plasma cells and $\mathrm{T}$ lymphocytes in different organs. The levels of serum IgG4 and immunostaining with an anti-IgG4 antibody are helpful in making the diagnosis.

The pathology named as inflammatory pseudotumor consists of a heterogeneous group of lesions occurring in different organs. It is histologically characterized by fibroblastic and myofibroblastic proliferation along with an inflammatory infiltrate. ${ }^{[3]}$

Herein, we present a case with IgG4-related sclerosing vasculitis presented with periaortitis, coronary vasculitis, and a retrobulbar pseudotumor. The presenting symptoms of this case are atypical and may help clinicians with similar cases.

\section{CASE REPORT}

A 61-year-old male patient was admitted to our outpatient unit with dyspnea, edema on the legs, and chest pain. The physical examination was unremarkable except for exophthalmos, tachypnea, S3 edema, and bilateral pretibial pitting edema, and the laboratory investigation revealed the following levels: blood urea nitrogen $94 \mathrm{mg} / \mathrm{dL}$, creatinin $1.38 \mathrm{mg} / \mathrm{dL}$, and C-reactive protein (CRP) $1.53 \mathrm{mg} / \mathrm{dl}$. The anti

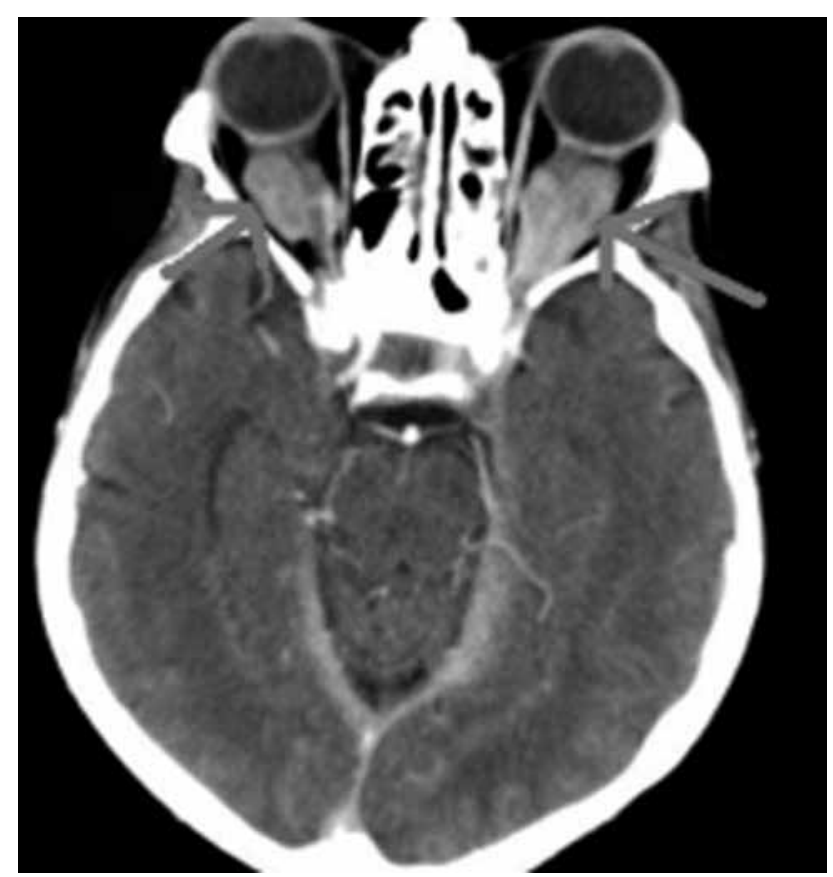

Figure 1. Bilateral retro-orbital pseudotumor $(16 \mathrm{~mm}$ on the right side and $19.5 \mathrm{~mm}$ on the left side). nuclear antibody (ANA) revealed a negative result. The globulin levels were within normal limits; therefore, IgG and $\mathrm{E}$ levels were not analyzed. The patient had no history of autoimmune or allergic diseases. An echocardiographic evaluation was performed to rule out heart failure and massive pericardial effusion, and a mass at the right atrial wall was detected. Nearly 1500 cc pericardial fluid was aspirated by pericardiosynthesis for the relief of the dyspnea. The examinations for tuberculosis revealed negative results, but atypical mesothelial and inflammatory cells were seen in the cytological evaluation. Therefore, computed tomography (CT) of the abdomen and thorax was ordered for further evaluation and pericardial effusion and periaortitis was detected beginning from the arcus and lasting to the abdominal aorta (Figures 1 and 2). On the cardiac CT scan, three soft tissues arising from the right coronary artery and extending to the right atrium were seen (Figure 3). The serologic tests for perinuclear anti-neutrophil cytoplasmic antibodies (p-ANCA) and cytoplasmic anti-neutrophil cytoplasmic autoantibody (c-ANCA) were negative. The radiological evaluation of the exophthalmos with cranial CT revealed bilateral retro-orbital pseudotumors, although the thyroidstimulating hormone level was normal (Figure 4). By all of these radiological findings, IgG4-related sclerosing vasculitis was first suspected, and the level of IgG4 was found to be $148(0-125) \mathrm{U} / \mathrm{ml}$. The patient was referred to the cardiovascular surgeons for a biopsy from the mass in the right atrium. The histological evaluation of the biopsy material revealed lymphoplasmacytic infiltration fibrosis, a lymphoid follicle, and eosinophilic infiltration. These findings were concordant with IgG4-related sclerosing vasculitis. The arterial constrictions in the right coronary artery and circumflex artery were removed by percutaneous balloon angioplasty and two cardiac stents a cardiac pacemaker were implanted.

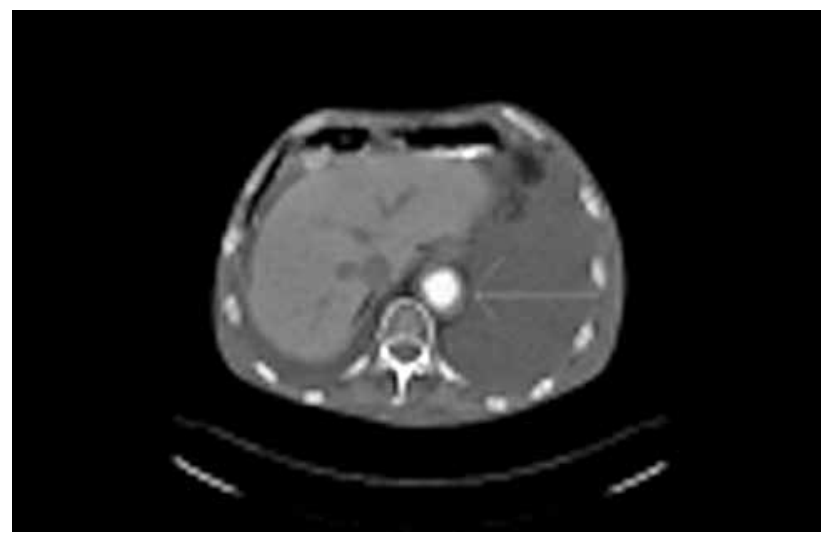

Figure 2. Periaortitis around the abdominal part of the aorta. 


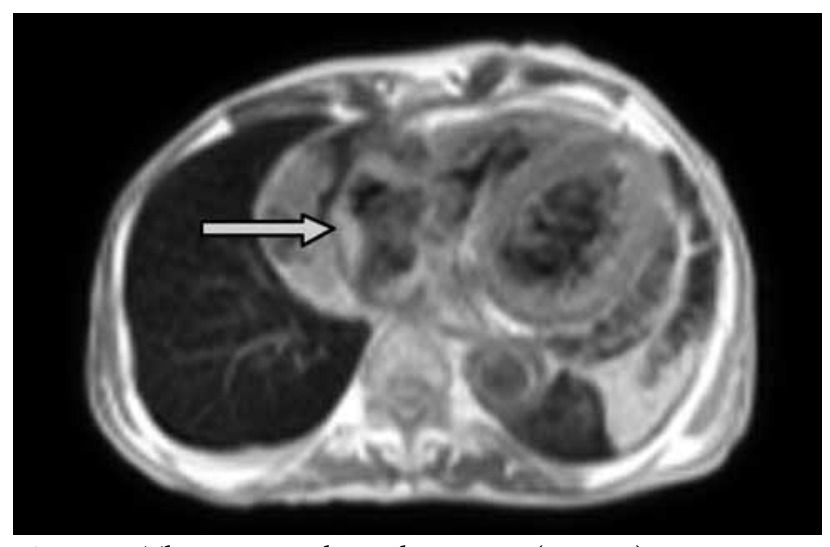

Figure 3. The mass in the right atrium $(22 \mathrm{~mm})$.

The appropriate treatment was ordered as a pulse steroid of $1000 \mathrm{mg}$ prednisolone and 500 mg cyclophosphamide every month in conjunction with oral immunosuppressive therapy. A radiological evaluation after three months revealed significant response and regression of the lesions. The mass in the right atrium had decreased to $16 \mathrm{~mm}$, and the lesion on the retro-orbital area had decreased to $11 \mathrm{~mm}$ on the right and $12 \mathrm{~mm}$ on the left.

\section{DISCUSSION}

The relatively new entity named as IgG4-related sclerosing disease is a systemic pathology characterized by the infiltration of IgG4-positive plasma cells and $\mathrm{T}$ lymphocytes in various organs. ${ }^{[1-3]}$ The most frequently affected organs are the pancreas, bile duct, gallbladder, salivary gland, retroperitoneum, kidneys, lungs, and prostate while the most usual pathology is fibrosis with obliterative phlebitis.

Autoimmune pancreatitis is not simply pancreatitis, but it is a sign of IgG4-related sclerosing disease. Most of the IgG4-related sclerosing diseases are associated with AIP, but IgG4-related sclerosing diseases without pancreatic involvement are also present in the literature. To our knowledge, our case is the first with periaortitis and coronary vasculitis. Sometimes inflammatory pseudotumors are also found as a part of the disease, and, in our case, there were bilateral retro-orbital pseudotumors around the optic nerves. It is known that AIP is mainly a disease of older men, as in our case, and that it responds well to steroid therapy. Our patient also benefited from intravenous pulse and oral steroids.

Stone et al., ${ }^{[5]}$ reported a case of IgG4-related systemic disease associated with a dissection in the ascending aorta and stated that features of IgG4-related

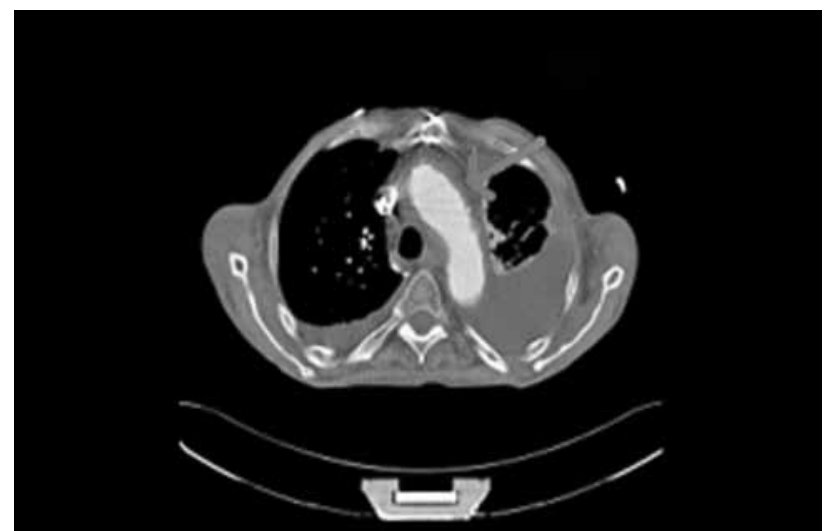

Figure 4. Periaortitis around the aortic arcus $(9 \mathrm{~mm})$.

systemic disease detected in the aortic surgery could be mistaken for features of a number of rheumatic disorders, such as giant cell arteritis and isolated aortitis or some malignancies, for example lymphoproliferative diseases, squamous cell carcinoma, and malignant melanoma. As the recognition of IgG4-related systemic disease increases as a clinical entity, more clinicians will consider this diagnosis in patients with any type of idiopathic aortitis or chronic periaortitis. ${ }^{[6]}$

Matsumoto et al ${ }^{[7]}$ reported a case presenting with an abdominal aortic aneurysm and a tumorous lesion around the right coronary artery. The patient was later diagnosed with IgG4-related systemic disease, but his lesions were not as widely separated as those in our case, and he did not have aortitis, but an aneurysm.

Large-vessel vasculitides, for instance giant cell arteritis, Takayasu arteritis, Behcet's syndrome, and Cogan's syndrome along with rheumatoid arthritis (RA), ankylosing spondylitis, systemic lupus erythematosus, and relapsing polychondritis may present with noninfectious aortitis. Also, sarcoidosis may cause aortitis and is difficult to distinguish from Takayasu arteritis. Most of these conditions affect the ascending aorta. ${ }^{[8-16]}$

The first vascular lesions in IgG4-related systemic disease were described by Kasashima et al., ${ }^{[17]}$ as an abdominal aortic aneurysm. Two years later, the same author reported similar lesions in the thoracic aorta. ${ }^{[18]}$

Recently some of the cases of chronic periaortitis have been recognized to be a part of IgG4-related systemic disease. ${ }^{[19]}$ The histopathological features of the organs affected by IgG4-related systemic disease are similar, with characteristic findings including dense lymphoplasmacytic inflammation, sclerosis, periductal inflammation, acinar atrophy, inflammatory 
pseudotumors of the involved organ, and obliterative phlebitis. ${ }^{[20]}$ On the histological evaluation, periductal granulomas, lymphoplasmacytic infiltrates with positive staining for IgG4, and multinucleated giant cells may be seen, with elevated serum levels of IgG4 in $75 \%$ of patients. The best differential diagnosis of IgG4-related systemic disease can be done with numerous infiltrating IgG4-positive plasma cells on the biopsy and high serum IgG4 concentrations.

In conclusion, we provide herein the first report of a patient with IgG4-related systemic disease associated with periaortitis, coronary vasculitis, and a retroorbital pseudotumor. According to the results in this case, we also advise evaluating patients with chronic periaortitis for IgG4-related systemic disease.

\section{Declaration of conflicting interests}

The authors declared no conflicts of interest with respect to the authorship and/or publication of this article.

\section{Funding}

The authors received no financial support for the research and/or authorship of this article.

\section{REFERENCES}

1. Yoshida K, Toki F, Takeuchi T, Watanabe S, Shiratori K, Hayashi N. Chronic pancreatitis caused by an autoimmune abnormality. Proposal of the concept of autoimmune pancreatitis. Dig Dis Sci 1995;40:1561-8.

2. Hamano H, Kawa S, Horiuchi A, Unno H, Furuya N, Akamatsu T, et al. High serum IgG4 concentrations in patients with sclerosing pancreatitis. $\mathrm{N}$ Engl J Med 2001;344:732-8.

3. Kamisawa T, Okamoto A. Autoimmune pancreatitis: proposal of IgG4-related sclerosing disease. J Gastroenterol 2006;41:613-25.

4. Kamisawa T, Egawa N, Nakajima $H$, Tsuruta $K$, Okamoto A, Hayashi Y, et al. Gastrointestinal findings in patients with autoimmune pancreatitis. Endoscopy 2005;37:1127-30.

5. Stone JH, Khosroshahi A, Hilgenberg A, Spooner A, Isselbacher EM, Stone JR. IgG4-related systemic disease and lymphoplasmacytic aortitis. Arthritis Rheum 2009;60:3139-45.

6. Vaglio A, Corradi D, Manenti L, Ferretti S, Garini G, Buzio C. Evidence of autoimmunity in chronic periaortitis: a prospective study. Am J Med 2003;114:454-62.

7. Matsumoto Y, Kasashima S, Kawashima A, Sasaki H, Endo M, Kawakami K, et al. A case of multiple immunoglobulin G4-related periarteritis: a tumorous lesion of the coronary artery and abdominal aortic aneurysm. Hum Pathol 2008;39:975-80.

8. Haynes BF, Kaiser-Kupfer MI, Mason P, Fauci AS. Cogan syndrome: studies in thirteen patients, long-term followup, and a review of the literature. Medicine (Baltimore) 1980;59:426-41.

9. Cochrane $\mathrm{AD}$, Tatoulis J. Coga's syndrome with aortitis, aortic regurgitation, and aortic arch vessel stenoses. Ann Thorac Surg 1991;52:1166-7.

10. Lie JT. Illustrated histopathologic classification criteria for selected vasculitis syndromes. American College of Rheumatology Subcommittee on Classification of Vasculitis. Arthritis Rheum 1990;33:1074-87.

11. Lie JT. Aortic and extracranial large vessel giant cell arteritis: a review of 72 cases with histopathologic documentation. Semin Arthritis Rheum 1995;24:422-31.

12. Hotchi M. Pathological studies on Takayasu arteritis. Heart Vessels Suppl 1992;7:11-7.

13. Chikamori T, Doi YL, Yonezawa Y, Takata J, Kawamura M, Ozawa T. Aortic regurgitation secondary to Behçet's disease. A case report and review of the literature. Eur Heart J 1990;11:572-6.

14. Kerr GS, Hallahan CW, Giordano J, Leavitt RY, Fauci AS, Rottem M, et al. Takayasu arteritis. Ann Intern Med 1994;120:919-29.

15. Gravallese EM, Corson JM, Coblyn JS, Pinkus GS, Weinblatt ME. Rheumatoid aortitis: a rarely recognized but clinically significant entity. Medicine (Baltimore) 1989;68:95-106.

16. Weiler V, Redtenbacher S, Bancher C, Fischer MB, Smolen JS. Concurrence of sarcoidosis and aortitis: case report and review of the literature. Ann Rheum Dis 2000;59:850-3.

17. Kasashima S, Zen Y, Kawashima A, Konishi K, Sasaki H, Endo $\mathrm{M}$, et al. Inflammatory abdominal aortic aneurysm: close relationship to IgG4-related periaortitis. Am J Surg Pathol 2008;32:197-204.

18. Kasashima S, Zen Y, Kawashima A, Endo M, Matsumoto Y, Kasashima F, et al. A clinicopathologic study of immunoglobulin G4-related sclerosing disease of the thoracic aorta. J Vasc Surg 2010;52:1587-95.

19. Kamisawa T, Okamoto A. IgG4-related sclerosing disease. World J Gastroenterol 2008;14:3948-55.

20. Deshpande V, Chicano S, Finkelberg D, Selig MK, MinoKenudson M, Brugge WR, et al. Autoimmune pancreatitis: a systemic immune complex mediated disease. Am J Surg Pathol 2006;30:1537-45. 